Article

\title{
External Financing, R\&D Intensity, and Firm Value in Biotechnology Companies
}

\author{
Namryoung Lee ${ }^{1}$ and Jaehong Lee ${ }^{2, *}$ (i) \\ 1 School of Business, Korea Aerospace University, Goyang 10540, Korea \\ 2 College of Business, Sangmyung University, Seoul 03016, Korea \\ * Correspondence: jaehong321@gmail.com
}

Received: 28 June 2019; Accepted: 29 July 2019; Published: 31 July 2019

check for updates

\begin{abstract}
Focusing on biotechnology firms, this study analyzes the relationship between the level of intensity of the research and development (R\&D) conducted by a firm, the debt financing decisions the firm makes, and the overall value of the firm. The data presented shows that, although most firms are unlikely to acquire financing from the debt market, the opposite is true for firms in the biotechnology industry. One reason for this divergence may be the belief among biotechnology firms that their future commercial success depends on their ability to develop new products, resulting in a strategy of intense R\&D. Furthermore, an examination of firm values reveals that while most firm values are negatively correlated with leverage and R\&D intensity, biotechnology firm values show no such correlation, implying that biotechnology firms prioritize sustainable commercial success no matter the source of financing.
\end{abstract}

Keywords: debt financing; equity financing; R\&D intensity; firm value; biotechnology companies JEL classification

\section{Introduction}

Innovation is essential to driving economic development, ensuring the long-term sustainability of a firm, and improving quality of life throughout society. The innovations implemented by a firm are usually generated from sources of information that have been established as a part of its normal operation. One such source is research and development (R\&D), perhaps the most common innovation generator [1]. In the United States, between 1991 and 2013, firms spent approximately 7\% of their total assets on R\&D. In that time, the amount spent on R\&D jumped from roughly 3.7\% of total assets in 1991 to about $10 \%$ in the late 1990 s before settling at close to $7 \%$ until the early 2010 s. This can be interpreted as evidence that intangible assets, such as customer relations, brand reputation, intellectual property, and employee conduct, are becoming more valuable [2]. The sustainability of a firm therefore depends on its ability to constantly and effectively innovate and differentiate itself in these areas [2,3].

Based on its national innovation system, South Korea recently invested in the R\&D of a select group of promising future industries. Two of these industries, biotechnology and electronics, are expected to be at the core of Korea's economic future. In fact, biotechnology stocks were the most popular stocks on the Korean stock market in 2018, and eight of the ten fastest-growing stocks belonged to the industry. These biotechnology shares are characterized by consistent $R \& D$ investments despite reports of poor short-term performance. As a result, the KRX Healthcare Index, which represents the stock flow of domestically listed pharmaceutical and biotechnology companies, rose 4.8 percent in 2018, higher than the 3.5 percent gain for the KOSPI as a whole during the same period. For reference, the KRX Healthcare Index consists of 75 pharmaceutical and biotechnology stocks in the KOSPI and KOSDAQ markets, including Celltrion, Celltrion Healthcare, and Hanmi Pharmaceutical. 
Though many biotechnology firms are recording financial losses, their market values continue to rise as investors anticipate future increases in values. This expected jump in valuation depends on the success of R\&D, which, due to the nature of biotechnology firms, requires a substantial amount of funding. On average, the development of one product costs approximately $\$ 800$ million [4], so in order to sustain operation in the highly competitive market, these firms must receive investments in R\&D. This need for reliable and constant R\&D funding makes investing in biotechnology firms potentially risky. Though dedicating resources to $R \& D$ is vital to the sustainability and growth of the firm, the often intangible results of R\&D mean that a significant investment comes with an equally significant risk [5].

Firms generally rely on equity financing through the stock market, rather than debt financing, to fund R\&D because of its intangible nature and consequent lack of collateral value [6]. Investors may be eager to support firms seeking this funding because R\&D has been shown to produce strong growth opportunities [7-9]. According to agency theory, firms with more growth options wield less leverage due to both underinvestment [10] and asset substitution problems [11]. When firms are forced to acquire debt financing, short-term debt is preferred because it matures prior to the execution of the investment option. Such firms also distribute lower dividends, since available cash flow is absorbed completely by growth opportunities [12]. Since the financial market is the primary source of R\&D funding, this financing decision issue is vital to the sustainability of many firms.

This study focuses on that issue, examining the relationship between the intensity of R\&D and debt financing. Since R\&D is rarely funded by debt financing, this relationship has largely been overlooked. Of the relatively few studies that do examine this relationship, some find that R\&D activity is significantly affected by debt capital $[13,14]$. In one such study, Amore et al. [13] discover that a firm is more likely to actively pursue innovation if it has easy access to banking. Evidence of this relationship between innovation and debt financing suggests that $R \& D$ activities may affect debt financing. On the one hand, since $R \& D$ can create uncertainty regarding the future opportunities of a firm and generate information asymmetry between management and debtholders [15-17], investing in R\&D poses a risk to creditors, which lowers a firm's leverage [18]. On the other hand, a dedicated focus on R\&D can also generate more sustainable opportunities and profits for a firm [19]. Unlike equity holders, debtholders benefit exclusively from the sum of principal and interests, so firms that steadily invest in $R \& D$ are able to create value for debtholders by sustaining profits through continuous development, thereby ensuring the repayment of debts.

In this study, we attempt to connect these seemingly opposing arguments by considering the evolving attitudes debtholders have towards $R \& D$ in various industries. In particular, the biotechnology companies defined in this study include only biopharmaceutical technology and bio-pharmaceutical companies. Understanding the difficulty firms that depend on $R \& D$ have in offering collateral to potential debt lenders, we expect their leverage ratios to be lower. At the same time, we expect biotechnology companies to exhibit somewhat different tendencies, since R\&D investment is especially high and considered to be especially vital to sustainable commercial success in this industry. This study further analyzes the effects intense $R \& D$ and high leverage have on the value of a firm. Among biotechnology firms, we expect this relationship to be uniquely imperceptible.

The ensuing paper is structured as follows: Section 2 reviews previous literature and presents hypotheses, Section 3 describes the research design and explains the selection process of the data sample, Section 4 presents the empirical results, and Section 5 concludes the paper.

\section{Related Research and Hypothesis Development}

\subsection{Capital Structure and Firm Value}

Modigliani and Miller [20] presented the irrelevance theory, claiming that if the capital market is perfect, firm value is irrelevant from capital structure. Later, diverse discussions arose as a study on financial structure mitigated Modigliani and Miller's unrealistic factor of a 'perfect' capital market. 
Especially, in 1963, Modigliani and Miller mitigated the hypothesis that no corporate tax exists from the market incomplete factor. They modified it by claiming that when considering corporate tax, the firm's value would increase the more the firm holds debts due to the tax shield from interest expense. Whereas, Miller [21] stated that when considering both corporate tax and individual income tax, capital structure would not influence firm value due to the clientele effect.

Capital structure theory with Modigliani and Miller's modified theory at the center later led to many studies focusing on maximizing firm value through the optimal capital structure. Capital structure theory has been studied empirically by mainly two methods. One is the static tradeoff theory which considers bankruptcy cost theory and agency theory. The other is the capital structure theory that includes information asymmetry such as the signaling theory and pecking order theory.

First, the key to static eclectic theory is that in the case of considering bankruptcy cost, an optimal capital structure can exist when additional financial distress cost matches the interest tax shield that occurs according to debt increase. When considering bankruptcy cost, the bankrupt firm's value decreases according to the compensation cost for creditors, shareholders and other people of the third party. Thus, the bankrupt firm's value could become even lower than the discount value of the expected operating cash flow due to dead-weight losses related to bankruptcy. Baxter [22] was first to show that using this information could explain the existence of optimal capital structure. Scott [23] claimed that if bankruptcy cost is acknowledged, optimal capital structure would be in relation with the mortgage value of the firm's tangible assets. Hence, if the firm does not hold enough mortgage assets to sustain debt, firm value would fall when financial leverage rises over a certain point.

Myers [10] also showed that firms with mortgage power tend to make debt rather than use their own capital when transferring wealth of the firm's creditors to the shareholders. Jensen and Meckling [11] used the agency theory and stated that the optimal leverage could be explained by the fact that the probability distribution provided by the firm cannot be independent from the ownership structure of the firm. Harris and Raviv [24] attempted to generalize the static tradeoff theory. Nondebt tax shield, firm size, tangible asset, and investment opportunity have positive relations with leverage. Conversely, bankruptcy cost, asset specificity, $R \& D$ cost, and advertisement expense have negative relations with it.

Second, the separation of ownership and control under modern capitalism [25], gave rise to the problem of agency. Also, the phenomenon of asymmetric information occurred as managers gained more information than shareholders. Ross [26] stated that capital structure can be used to signal the positive firm value. A firm could raise its debt level to increase its value by proving to be a good type of firm. When the firm issues its debt, bankruptcy cost would rise at the same time. The scale of bankruptcy cost would be able to be handled by firms that are good enough to cover their debts; however, it would be too large for nongood firms, which would block them from copying the financing structure.

Myers and Majluf [27] document that information asymmetry between the managements and outside investors is an important determinant of external financing. This theory is called the pecking order and it argues that debt financing decisions precede equity financing since information asymmetry problem is relatively weaker for debt financing due to its ability to manage confidential information. Given that equity investors suffer more from information asymmetry problems than debt holders, in circumstances where managers act for the interest of existing shareholders, they will not issue shares if the value of the corporate current assets is undervalued in the market, but prefer debt to reduce the information asymmetry problem.

Rajan and Zingales [28] analyzed whether certain factors affecting an entity's capital structure are similar in other G7 advanced countries. These factors are the ratio of market-to-book ratio, property, plant and equipment, profitability, and the firm size. In other words, the larger the size of the firm and the more tangible assets, the higher the debt ratio, and the higher the profitability and the market-to-book ratio, the lower the debt ratio. In line with this, Titman and Wessels [7] reported that an entity's originality and profitability had a negative relationship to its debt ratios. 
Fama and French [29] simultaneously validated the pecking order theory and static tradeoff theory with respect to dividends and liabilities in the 1965-1999 data. They showed that profitability had a positive correlation with the debt ratio, supporting the pecking order theory, which contradicted the static tradeoff theory. In addition, the size of the investment showed a negative relationship with the leverage to meet static tradeoff and the pecking order theory at the same time.

Although the existing literature has established much useful and essential information on capital structure, the answers to the question on the intra-industry variation of capital structure are still far from conclusive. In other words, two main trends of theoretical framework, the static tradeoff and pecking order models, to identify the determinants of capital structure seem to be violated to some degree in the real setting. Moreover, in prior studies, the relationship between R\&D intensity, capital structure, and corporate value has never been investigated considering intraindustry characteristics.

\subsection{Hypothesis Development}

Though the outcome of R\&D is generally uncertain, and its impact is rarely immediate, investment in $R \& D$ has been shown to generate future growth opportunities, potentially increasing profits and giving the firm a competitive advantage [30,31]. As competition in a market increases, firms are forced to find new opportunities for growth and push products to market ahead of their competition. Firms are therefore incentivized to develop new products, prioritizing commercial viability as quickly as possible. It is evident that investment in $R \& D$ generates value for a firm by providing a competitive advantage in the development of its products. Despite this understanding, relatively little research has been done on the sources of R\&D financing.

The availability of capital is vital to the successful execution of the strategies of a firm. Supplied by debtholders and shareholders, the primary sources of capital are debt and equity, which have unique characteristics and benefits. The decision to finance via debt or equity determines how the firm's economic rents are to be distributed between investors as well as the degree of control they have over the assets of the firm. Though numerous studies have been conducted on these capital structures over the last 50 years, the consequences of choosing one over the other have been relatively unexplored. Furthermore, the factors that drive firms to choose a specific form of financing are still unclear.

Though prior studies are somewhat mixed, corporate capital structure is generally affected by factors such as firm size, profitability, tangible assets, and market-to-book ratio [7,27,28]. Classical theories of capital structure offer potential insight into why firms who conduct intense R\&D may choose one source of finance of another. The pecking-order hypothesis, for example, proposes that, due to their high degree of information asymmetry, innovative firms find equity financing difficult [27]. Another theory, the bankruptcy cost hypothesis, suggests that R\&D-centric firms usually have low debt ratios, because they lack collateral and have difficulty adhering to a strict payment schedule due to the unpredictability of their R\&D results [23]. In prior literature, debt is generally not considered a viable option to fund $R \& D$, especially if the firm is young and R\&D-centric. This is because debt contracts are inflexible, and the fixed payment schedule can be difficult for a firm with high R\&D intensity. Furthermore, the collateral value of such a firm's assets, which are generally intangible, is often insufficient.

R\&D comes with inherent risk, and due to the exploratory nature of innovation, many R\&D projects do not produce tangible results. When an R\&D project fails, firms lose both the initial investment and the potential future sales of the product [32]. R\&D is intangible and unique to each firm, a combination that results in information asymmetry [15,33], making it difficult for capital markets to accurately predict future returns [16]. Together, the likelihood of failure and the ensuing asymmetrical information environment make R\&D a cash flow liability [34]. Since creditors are sensitive to an increased risk of default, investing in R\&D can lower the creditworthiness of a firm, subsequently decreasing the opportunity for debt financing [18].

R\&D produces growth development [7-9], which, according to agency theory, results in what is called an underinvestment problem [10]. In short, an indebted firm has fewer investment possibilities. 
Since an increase in debt value is not beneficial to shareholders, a manager working in the best interest of those shareholders may refuse to act on growth opportunities, which only increase debt value once a certain level of debt has been reached. Indeed, firms may discard profitable projects if they result in a higher debt value, funneling the potential profits of the project to debtholders.

This study builds upon the existing literature regarding the relationship between R\&D and debt financing by relating the intensity of $R \& D$ to the leverage firms have. We will also compare these findings to the tendencies of biotechnology firms, whose primary activity is sustainable development through investment in $\mathrm{R} \& \mathrm{D}$, which can inversely affect the benefits of creditors. Biotechnology firms' R\&D contributes to the accumulation of information and experience by the employees of a firm, which ultimately inspires the adoption of new long-term problem-solving routines [35,36]. Furthermore, R\&D investments in these firms generates Schumpeterian rents for firms that bring new products to market [37]. Though these Schumpeterian rents dissolve as new products become ubiquitous, they can be renewed through continual innovation by the firm [19]. Studies show that neglecting R\&D and ignoring potential opportunities and changes in the market can lead to the failure of a firm [38]. Since creditors suffer when a firm defaults, firms with proven sustainability through R\&D investments have increased creditworthiness by consistently investing in core activities. Therefore, biotechnology firms can improve their creditworthiness by investing in R\&D, thereby creating value for creditors. Considering this, the first hypothesis is as follows:

Hypothesis 1 (H1). Firms with high RED intensity will be less likely to finance from the debt market, but this will not be the case for biotechnology firms.

Though the value created by $R \& D$ is intangible and hard to measure, the market value of the firms with high R\&D intensity reflects that value to some degree because the valuation process incorporates the assessment of the feasibility of R\&D investments. Rather than waiting for an innovation to become a commercial product, a valuation can occur in anticipation of expected future returns while the product is still being developed. With this is mind, the market value of a firm can be used to determine the predicted success of an individual product or a firm's $R \& D$ as a whole in the long-term perspective.

As prior studies have shown, investment in $R \& D$ usually has a positive effect on the market value of a firm [39-42], and corporate R\&D investment is essential to the growth of a firm [40]. Increases in $R \& D$ investments are generally considered vital activities for the corporate long-term innovation. For example, Walwyn [43] found that investments in R\&D obviously increased the competitiveness of firms by analyzing the cellphone industry in Finland. Looking at research and development activity individually, Karlsson et al. [44] found that the productivity of a firm can be measured by its research activities, while development is the process of shaping that research into a commercial product. Considering both aspects results in a more complete assessment of a firm's investment in R\&D.

On the other hand, several research studies have found a negative correlation between investment in R\&D and the value of a firm. Hall [45], for example, finds that stock market valuation of R\&D capital among manufacturing firms in the US crashed between 1979 and 1983 and again between 1986 and 1991, and he goes on to show that the expected cash flow produced from R\&D investments is four time less than the expected cash flow from other investments. According to Erickson and Jacobson [46], the market value of a firm is no more increased by investments in R\&D and advertising than by any other kind of investment; they argue that the positive correlation between R\&D investment and performance in the stock market reported elsewhere is actually a coincidental result of a firm's overall increase in profitability. Another argument against the value-increasing power of R\&D is the relative risk and high information asymmetry of R\&D investments when compared to more tangible ones. Honore et al. [47] show that firms more actively engaged in R\&D display a high degree of information asymmetry between managers and investors, negatively affecting the value of those firms. Assuming that high leverage results in underinvestment, it follows that leverage negatively affects the value of a firm. McConnell and Servaes [48] support this claim by showing that leverage 
in high-growth firms is negatively correlated to Tobin's Q. Cai and Zhang [49], who group firms into portfolios based on the change in monthly leverage, find that, in the three-factor model of Fama and French [50], the alpha is negatively correlated to leverage. These findings imply that high leverage in a firm produces suboptimal investment policies. Therefore, in order to take advantage of growth opportunities, firms with a significant amount of debt that intensely engage in $R \& D$ are incentivized to rebalance their capital structures. This is especially true for high-leverage private firms, which have difficulty deleveraging, since they do not have access to the public equity market.

Our second hypothesis analyzes the relationship between the intensity of $R \& D$ and the value of high-leverage firms. We also compare these relationships to the tendencies of biotechnology firms. There has been a large amount of interest in drawing a link between investment in R\&D and the value of a firm. Osawa and Yamasaki [51] find three inhibiting factors researchers face when searching for this connection: the lack of a definitive measurement of R\&D performance, the gap in time between the initial investment in R\&D and the ultimate results, and the dearth of well-established techniques and concepts for future projects, which prevents the adoption of appropriate indices and undermines the standardization of an R\&D measurement. As the gap in time grows between R\&D investments and results, it becomes more difficult for high-leverage firms to quantify the impact of those investments. Therefore, as R\&D intensity and leverage increase, we expect firm value to decrease.

We expect biotechnology firms, however, to demonstrate different tendencies. For firms that conduct intense R\&D, such as biotechnology firms, a lack of funding is especially detrimental, since it stunts the growth of the firm by limiting vital R\&D activity. Therefore, such firms must find sources, presumably external ones, to finance the large amount of $R \& D$ necessary for growth. In cases such as these, transparency can be both an asset and a liability. On the one hand, transparency increases information symmetry, making the firm more attractive for investors, which in turn benefits R\&D. On the other hand, oversharing information can, depending on the strength of protections where the firm is based, compromise the value of intellectual property. This is called a proprietary costs problem, and it is especially relevant to biotechnology firms with a high degree of growth option, as they also have valuable proprietary information. Therefore, these firms would ideally be high-leverage firms, as debtholders are adept at managing proprietary corporate information.

In the framework of capital structure, financing tools can be analyzed based on maturity, as long-term debt matures after at least one year, while short-term debt is due within one year. According to corporate finance theory, long-term debt is more expensive than short-term debt [52]. We therefore expect that the market is less negative for high-leverage, R\&D-intensive companies with a large proportion of short-term debt. On the other hand, this is not the case if that firm is a biotechnology firm. Therefore, the second hypotheses are as follows:

Hypothesis 2 (H2). For high-leverage firms, high RED intensity will negatively impact firm value, but this will not be the case for biotechnology firms.

Hypothesis 3 (H3). The use of short-term debt will mitigate the negative impact of debt financing, but this will not be the case for biotechnology firms.

\section{Research Design}

\subsection{Sample Selection}

This research uses data from the Korea Investors Service, Inc., and chooses 2000-2017 as the sample period. The sample includes publicly traded firms on the Korean Stock Exchange having a fiscal year-end of 31 December, but firms in the financial industries are excluded. All continuous variables are winsorized at the top $1 \%$ and bottom $1 \%$. The final sample consists of 26,535 firm-year observations, with $6.28 \%$ of the sample firms being biopharma or biotech firms. Table 1 below presents sample distribution by industry. 
Table 1. Sample distribution by industry.

\begin{tabular}{lcc}
\hline \multicolumn{1}{c}{ Industry } & Number of Firms Years & $\%$ \\
\hline Agriculture/Fishing/Forestry/Mining & 122 & 0.46 \\
Manufacturing & 15,827 & 59.65 \\
Electricity/Environment/Water & 258 & 0.97 \\
supply & 939 & 3.54 \\
Construction & 1959 & 7.38 \\
Retail/Wholesale & 445 & 1.68 \\
Transportation/Warehousing & 28 & 0.11 \\
Lodging/Restaurants & 1914 & 7.21 \\
Broadcasting/Communication/Publication & 832 & 3.14 \\
Computer/Information/Medical & 66 & 0.25 \\
Leasing/Real Estate/Renting & 1667 & 6.28 \\
Biopharma/Biotech & 2478 & 9.34 \\
Others $\quad$ Total & 26,535 & 100 \\
\hline
\end{tabular}

\subsection{Regression Model and Measurement of Variables}

The following Ordinary Least Squares (OLS) regression model is used to examine Hypothesis 1:

$$
\begin{aligned}
\text { LEVERAGE }_{\mathrm{i}, \mathrm{t}}=\alpha & +\beta 1 \text { R\&Dintensity } \\
& +\sum \alpha_{\mathrm{k}, \mathrm{t}}+\beta 2 \mathrm{IND}_{\mathrm{k}}+\sum \alpha_{\mathrm{l}} \mathrm{YEAR}_{\mathrm{l}}+\varepsilon_{\mathrm{i}, \mathrm{t}}
\end{aligned}
$$

Capital structure has an effect on firms' R\&D activities $[53,54]$. This study examines capital structure of R\&D intensive firms-biotech firms considering their unique nature. In this study, hypotheses are constructed and analyzed based on the following classical theories: According to the pecking order theory [27], firms first prefer the internal sources. Then, firms choose debt financing among external resources. However, another theory can also be applied for R\&D intensive firms-biotech firms, considering their specificities. Under static trade-off theory considering bankruptcy cost theory and agency theory, leverage is inversely related with R\&D intensity [24], and equity issuing is preferred to debt financing for the firms actively invest in R\&D [55]. On the other hand, biotech companies that require much more $R \& D$ funding are likely to be in an exceptional situation. For the analysis of the first hypothesis based on these theories, leverage is used as a dependent variable.

LEVERAGE $_{\mathrm{i}, \mathrm{t}}$, a dependent variable, is computed by dividing debts by assets. RDintensity $\mathrm{y}_{\mathrm{i}, \mathrm{t}}$ is calculated by dividing total $R \& D$ expenditures, which are both capitalized and expensed $R \& D$ investments, by sales. RDintensityBIO ${ }_{i, t}$ is the interaction between RDintensity and BIO, the biotechnology dummy variable, which refers to both biopharmaceutical and biotechnology firms.

As in prior capital structure studies, Xi.t is included as the other factor affecting capital structure decisions on LEVERAGE. We also included a tangibility of assets variable, which is calculated by dividing tangible assets by total assets. Size, which is the natural log of total assets, and growth of assets were also included. Return on asset (ROA), which is the net income divided by total assets, and the natural log of total sales were also included, as was liquidity, for which current assets are divided by current liabilities. IND is the industry sector dummy variable, defined by the single-digit Korea Standard Industry Code, and YEAR is the year dummy variable.

It is generally said that there is a positive relationship between R\&D intensity and firm value. However, higher leverage of high-growth firms tends to lower Tobin's Q [56]. Alternatively, R\&D intensive firms, such as biotech firms that crucially need $R \& D$ investment for sustainable competitiveness, are likely to be highly dependent on debt financing. Therefore, for the second 
hypothesis that analyzes the relationship between the intensity of $R \& D$ and the value of high-leverage firms, the following OLS model is employed, with Tobin's q as the dependent variable:

$$
\begin{aligned}
\text { Tobin's } \mathrm{q}_{\mathrm{i}, \mathrm{t}}=\alpha+ & \beta \text { HHRDINT }_{\mathrm{i.t}}+\beta 2 \text { HRDINTHLEV }_{\mathrm{i.t}}+\beta 3 \text { HRDINTHLEVbio }_{\text {i.t }} \\
& +\sum \alpha_{\mathrm{j}} \mathrm{X}_{\mathrm{j}}+\sum \alpha_{\mathrm{k}} \mathrm{IND}_{\mathrm{k}}+\sum \alpha_{\mathrm{l}} \mathrm{YEAR}_{1}+\varepsilon_{\mathrm{i}, \mathrm{t}}
\end{aligned}
$$

Tobin's q, which is equal to the market value of equity plus liabilities divided by total assets, is the most used to assess the value of a firm, as it is in prior studies [48,57-59]. HRDINT ${ }_{i, t}$ equals 1 if R\&D intensity is above the median and 0 otherwise. HRDINTHLEV $\mathrm{i}_{\mathrm{i}, \mathrm{t}}$ is the interaction between HRDINT and HLEV, which equals 1 if Leverage, total liabilities divided by total assets, is above the median. HRDINTHLEVbio $_{i, t}$ represents the interaction between HRDINTHLEV and BIO, the biotechnology dummy variable. Xi.t represents the other factors affecting Tobin's q, which are explained below, IND is the industry indicator variable, and YEAR is the year indicator variable. The model also includes control variables that can affect firm value, such as size, sales growth, leverage, investment, and market-to-book value. Size, which is the natural log of total assets, is included to control for side effects. Size is defined as the book value of total assets, and it may have a positive association with market value. Leverage is coded as 1 if the total liabilities divided by total assets is above the median, and it may have a negative correlation with market value [12]. Sales growth controls for growth, and the market-to-book ratio is calculated by dividing the market value of equity by the book value. The investment decisions of a firm may have an effect on firm value, so investment is used as a control variable. Finally, the industry sector dummy variable, defined by the single-digit Korea Standard Industry Code, and the year dummy variable are included as controls.

For debt financing, R\&D firms tend to particularly rely on short-term debt [60]. Myers [10] suggested that short-term debt positively impacts on firms' growth and is a way to avoid underinvestment. In this respect, we additionally examine whether the market less negatively assess high-leveraged, R\&D-intensive companies with a large proportion of short-term debt and the following OLS regression model is used to test Hypothesis 3.

To examine Hypothesis 3, the following OLS regression model was used.

$$
\begin{aligned}
\text { Tobin's } \mathrm{q}_{\mathrm{i}, \mathrm{t}}=\alpha & +\beta 1 \text { HRDINT }_{\mathrm{i.t}}+\beta 2 \text { HRDINTSTD }_{\mathrm{i.t}}+\beta 3 \text { HRDINTSTDbio }_{i . t} \\
& +\sum \alpha_{\mathrm{j}} \mathrm{X}_{\mathrm{j}}+\sum \alpha_{\mathrm{k}} \text { IND }_{\mathrm{k}}+\sum \alpha_{1} \text { YEAR }_{1}+\varepsilon_{\mathrm{i}, \mathrm{t}}
\end{aligned}
$$

STD equals 1 if long-term leverage is less than short-term leverage. HRDINTSTD $D_{i, t}$ represents the interaction between HRDINT and STD, and HRDINTSTDbio ${ }_{i, t}$ represents the interaction between HRDINTSTD and BIO, the biotechnology dummy variable. The model also includes control variables that can affect firm value, such as size, sales growth, STD, investment, and market-to-book value. Again, IND is the industry sector dummy variable, defined by the single-digit Korea Standard Industry Code, and YEAR is the year dummy variable.

\section{Empirical Results}

\subsection{Descriptive Statistics}

Table 2 shows the descriptive statistics for the variables. The mean (median) value for the two dependent variables, LEV and TQ are $0.4220(0.4198)$ and $1.3813(0.5816)$, respectively. The mean (median) values for the explanatory variables RDINT, RDINTbio, HRDINT, HRDINTHLEV, HRDINTHLEVbio, HRDINTSTD, and HRDINTSTDbio are 0.0122 (0.0040), 0.0087 (0), 0.5053 (1), 0.2390 (0), $0.0157(0), 0.1872(0)$, and $0.0136(0)$, respectively. 
Table 2. Descriptive statistics.

\begin{tabular}{cccccc}
\hline Variables & Mean & StdDev & Median & Q1 & Q3 \\
\hline LEV & 0.4220 & 0.2091 & 0.4198 & 0.2561 & 0.5727 \\
RDINT & 0.0122 & 2.3785 & 0.0040 & 0.0001 & 0.0040 \\
RDINTbio & 0.0087 & 0.3701 & 0 & 0 & 0 \\
Tangible & 0.2887 & 0.1945 & 0.2708 & 0.1345 & 0.4162 \\
Growth & 0.5270 & 2.7724 & -0.0364 & -0.1735 & 0.0522 \\
SIZE & 18.5675 & 1.4969 & 18.3605 & 17.5686 & 19.3327 \\
ROA & 0.0232 & 0.2643 & 0.0368 & 0.0045 & 0.0797 \\
Lnsales & 18.3055 & 1.6509 & 17.2237 & 18.1465 & 19.1948 \\
Liquidity & 3.2330 & 17.7200 & 1.5676 & 1.0163 & 2.7535 \\
TQ & 1.3813 & 2.9469 & 0.5816 & 0.3109 & 1.1562 \\
HRDINT & 0.5053 & 0.5000 & 1 & 0 & 1 \\
HLEV & 0.5032 & 0.5000 & 1 & 0 & 1 \\
HRDINTHLEV & 0.2390 & 0.4265 & 0 & 0 & 0 \\
HRDINTHLEVbio & 0.0157 & 0.1243 & 0 & 0 & 0 \\
STD & 0.3909 & 0.4880 & 0 & 0 & 1 \\
HRDINTSTD & 0.1872 & 0.3900 & 0 & 0 & 0 \\
HRDINTSTDbio & 0.0136 & 0.1159 & 0 & 0 & 0 \\
SalesGROW & 0.3835 & 2.2159 & -0.0205 & -0.0177 & 0.0747 \\
MTB & 1.3705 & 1.0436 & 1.0196 & 0.6183 & 1.7639 \\
INV & 0.2506 & 0.4946 & 0.1323 & 0.0547 & 0.1323 \\
\hline
\end{tabular}

Notes: LEV: Total liabilities divided by total assets. RDINT: Total R\&D investments divided by sales. RDINTbio: The interaction between RDINT and the biotech dummy variable. Tangible: Tangible assets divided by total assets. Growth: Assets growth, the changes in assets $=\left(\right.$ assets $_{\mathrm{t}}-$ assets $\left._{\mathrm{t}-1}\right) /$ assets $_{\mathrm{t}-1}$. SIZE: Natural logarithm of total assets. ROA: Net income divided by total assets. Lnsales: Natural logarithm of sales. Liquidity: Current assets divided by current liabilities. TQ: Tobin's $Q$, the market value of equity plus liabilities, all divided by total assets. HRDINT: Coded as 1 if R\&D intensity is above the median, and as 0 otherwise. HLEV: Coded as 1 if LEV is above the median. HRDINTHLEV: The interaction between HRDINT and HLEV. HRDINTHLEVbio: The interaction between HRDINTHLEV and BIO, the biotech dummy variable. STD: Coded as 1 if short-term leverage is greater than long-term leverage. HRDINTSTD: The interaction between HRDINT and STD. HRDINTSTDbio: The interaction between HRDINTSTD and BIO, the biotech dummy variable. SalesGROW: Sales growth, the changes in sales = $\left(\right.$ sales $_{\mathrm{t}}-$ sales $_{\mathrm{t}-1}$ )/sales $\mathrm{s}_{\mathrm{t}-1}$. MTB: Market-to-Book ratio, market value of equity divided by book value of equity. INV: Plant, property, and equipment (except land and construction in progress) divided by total assets.

Table 3 of Panel A and Panel B display the Pearson correlation results. Significant negative correlations are shown between the persistence of leverage (LEV) and RDINTbio $(p<0.1)$. Significant negative correlations are also shown between leverage and two of the control variables, ROA and Liquidity $(p<0.01)$. There are significant positive correlations between leverage and the control variables Tangible, Growth, SIZE, and Lnsales $(p<0.01)$. Significant positive correlations are also found between TQ and two explanatory variables, HRDINT and HRDINTHLEVbio $(p<0.01)$. Finally, significant positive correlations are observed between TQ and several control variables, including SIZE, SalesGROW, MTB, and INV $(p<0.01)$. Variance inflation factors (VIFs) are computed for all variables $<10$ in order to test for multicollinearity. With mean VIFs of 1.96 and 1.86, we conclude that no multicollinearity problems are evident. 
Table 3. Pearson correlations.

\begin{tabular}{|c|c|c|c|c|c|c|c|c|c|}
\hline \multicolumn{10}{|l|}{ Panel A } \\
\hline Variable & $L E V$ & RDINT & RDINTbio & Tangible & Growth & SIZE & $R O A$ & Lnsales & Liquidity \\
\hline LEV & 1.0000 & & & & & & & & \\
\hline RDINT & $\begin{array}{c}-0.0031 \\
0.6141\end{array}$ & 1.0000 & & & & & & & \\
\hline RDINTbio & $\begin{array}{c}-0.0102 \\
0.0972\end{array}$ & $\begin{array}{l}0.1555 \\
0.0000\end{array}$ & 1.0000 & & & & & & \\
\hline Tangible & $\begin{array}{l}0.2889 \\
0.0000\end{array}$ & $\begin{array}{l}0.0028 \\
0.6533\end{array}$ & $\begin{array}{c}-0.0216 \\
0.0004\end{array}$ & 1.0000 & & & & & \\
\hline Growth & $\begin{array}{l}0.0275 \\
0.0000\end{array}$ & $\begin{array}{c}-0.0088 \\
0.1505\end{array}$ & $\begin{array}{c}-0.0016 \\
0.7991\end{array}$ & $\begin{array}{l}0.0092 \\
0.1353\end{array}$ & 1.0000 & & & & \\
\hline SIZE & $\begin{array}{l}0.1051 \\
0.0000\end{array}$ & $\begin{array}{c}-0.0019 \\
0.7612\end{array}$ & $\begin{array}{c}-0.0271 \\
0.0000\end{array}$ & $\begin{array}{l}0.1337 \\
0.0000\end{array}$ & $\begin{array}{l}0.2290 \\
0.0000\end{array}$ & 1.0000 & & & \\
\hline$R O A$ & $\begin{array}{c}-0.1386 \\
0.0000\end{array}$ & $\begin{array}{c}-0.0030 \\
0.6278\end{array}$ & $\begin{array}{c}-0.0339 \\
0.0000\end{array}$ & $\begin{array}{c}-0.0035 \\
0.5728\end{array}$ & $\begin{array}{l}0.0008 \\
0.9014\end{array}$ & $\begin{array}{l}0.0512 \\
0.0000\end{array}$ & 1.0000 & & \\
\hline Lnsales & $\begin{array}{l}0.2198 \\
0.0000\end{array}$ & $\begin{array}{l}0.0253 \\
0.0000\end{array}$ & $\begin{array}{c}-0.0739 \\
0.0000\end{array}$ & $\begin{array}{l}0.1609 \\
0.0000\end{array}$ & $\begin{array}{l}0.0234 \\
0.0010\end{array}$ & $\begin{array}{l}0.8791 \\
0.0000\end{array}$ & $\begin{array}{l}0.0884 \\
0.0000\end{array}$ & 1.0000 & \\
\hline Liquidity & $\begin{array}{c}-0.1679 \\
0.0000\end{array}$ & $\begin{array}{c}-0.0027 \\
0.6608\end{array}$ & $\begin{array}{l}0.0207 \\
0.0007\end{array}$ & $\begin{array}{c}-0.1047 \\
0.0000\end{array}$ & $\begin{array}{l}0.0234 \\
0.0010\end{array}$ & $\begin{array}{c}-0.0201 \\
0.0010\end{array}$ & $\begin{array}{l}0.0060 \\
0.3301\end{array}$ & $\begin{array}{c}-0.1127 \\
0.0000\end{array}$ & 1.0000 \\
\hline \multicolumn{10}{|l|}{ Panel B } \\
\hline Variable & $T Q$ & HRDINT & HRDINTHLEV & HRDINTHLEVbio & SIZE & HLEV & SalesGR & W MTB & $I N V$ \\
\hline$T Q$ & 1.0000 & & & & & & & & \\
\hline HRDINT & $\begin{array}{l}0.1066 \\
0.0000\end{array}$ & 1.0000 & & & & & & & \\
\hline
\end{tabular}


Table 3. Cont

\begin{tabular}{|c|c|c|c|c|c|c|c|c|c|}
\hline Panel B & & & & & & & & & \\
\hline Variable & $T Q$ & HRDINT & HRDINTHLEV & HRDINTHLEVbio & SIZE & HLEV & \multicolumn{2}{|c|}{ SalesGROW MTB } & $I N V$ \\
\hline HRDINTHLEV & $\begin{array}{c}-0.0083 \\
0.2213\end{array}$ & $\begin{array}{l}0.5545 \\
0.0000\end{array}$ & 1.0000 & & & & & & \\
\hline HRDINTHLEVbio & $\begin{array}{l}0.0340 \\
0.0000\end{array}$ & $\begin{array}{l}0.1250 \\
0.0000\end{array}$ & $\begin{array}{l}0.2254 \\
0.0000\end{array}$ & 1.0000 & & & & & \\
\hline SIZE & $\begin{array}{l}0.1030 \\
0.0000\end{array}$ & $\begin{array}{c}-0.1157 \\
0.0000\end{array}$ & $\begin{array}{c}-0.0037 \\
0.5469\end{array}$ & $\begin{array}{c}-0.0465 \\
0.0000\end{array}$ & 1.0000 & & & & \\
\hline$H L E V$ & $\begin{array}{c}-0.1004 \\
0.0000\end{array}$ & $\begin{array}{c}-0.0612 \\
0.0000\end{array}$ & $\begin{array}{l}0.5568 \\
0.0000\end{array}$ & $\begin{array}{l}0.1255 \\
0.0000\end{array}$ & $\begin{array}{l}0.1068 \\
0.0000\end{array}$ & 1.0000 & & & \\
\hline SalesGROW & $\begin{array}{l}0.6701 \\
0.0000\end{array}$ & $\begin{array}{l}0.0134 \\
0.0290\end{array}$ & $\begin{array}{l}0.0277 \\
0.0000\end{array}$ & $\begin{array}{c}-0.0036 \\
0.5620\end{array}$ & $\begin{array}{l}0.2086 \\
0.0000\end{array}$ & $\begin{array}{l}0.0421 \\
0.0000\end{array}$ & 1.0000 & & \\
\hline MTB & $\begin{array}{l}0.3776 \\
0.0000\end{array}$ & $\begin{array}{l}0.1823 \\
0.0000\end{array}$ & $\begin{array}{l}0.1027 \\
0.0000\end{array}$ & $\begin{array}{l}0.0862 \\
0.0000\end{array}$ & $\begin{array}{c}-0.1272 \\
0.0000\end{array}$ & $\begin{array}{l}0.0011 \\
0.8724\end{array}$ & $\begin{array}{l}0.0234 \\
0.0006\end{array}$ & 1.0000 & \\
\hline$I N V$ & $\begin{array}{l}0.5812 \\
0.0000\end{array}$ & $\begin{array}{l}0.0096 \\
0.1180\end{array}$ & $\begin{array}{l}0.0709 \\
0.0000\end{array}$ & $\begin{array}{l}0.0184 \\
0.0026\end{array}$ & $\begin{array}{l}0.2381 \\
0.0000\end{array}$ & $\begin{array}{l}0.1072 \\
0.0000\end{array}$ & $\begin{array}{c}0.7540 \mathrm{z} \\
0.0000\end{array}$ & $\begin{array}{c}-0.0141 \\
0.0370\end{array}$ & 1.0000 \\
\hline
\end{tabular}

Note: See Table 2 for variable definitions. 


\subsection{Regression Results and Discussion}

Table 4 contains the regression results for Hypothesis 1, depicting the association between leverage and $R \& D$ intensity. As in the findings of prior studies, there is a significant negative correlation between leverage and R\&D intensity $(p<0.01)$. The correlation between leverage and $R \& D$ intensity is significantly positive $(p<0.01)$ for biotechnology firms, which supports Hypothesis 1 . Financing theories and previous studies suggest that debt financing is not a suitable way to raise R\&D funding. Most companies actually prefer equity financing to debt financing, especially for $R \& D$ investment. Biotechnology firms, big R\&D spenders, have found it increasingly difficult to secure equity financing. In particular, as described in the introduction, Korean biotechnology firms have recently struggled to raise equity funding through initial public offerings. Given funding constraints, small biotechnology firms often seek funding from venture capitalists (Financing and Investment Models in Industrial Biotechnology, OECD Workshop on the Outlook on Industrial Biotechnology, Vienna, 14 January 2010).

The results for Hypothesis 1 confirm that biotechnology firms have no choice but to rely on debt financing to invest in R\&D if there is a constraint on available financial resources. $R \& D$ is a key component of competitiveness and future sustainable growth. Hence, for such R\&D-intensive firms that are struggling with equity funding, investments are vital, even at the cost of debt.

There are significant correlations between LEV and the control variables. Growth, Tangible, and Lnsales have positive correlations with LEV, while ROA, SIZE, and Liquidity are negatively correlated. Additionally, robust regression analysis was performed, and the results remained consistent with the OLS results for the explanatory variables.

Table 4. Regression results.

\begin{tabular}{|c|c|c|c|}
\hline \multirow{2}{*}{ Variables } & \multirow{2}{*}{ Expected Sign } & \multicolumn{2}{|c|}{ Dependent Variable: $L E V$} \\
\hline & & OLS Regression & Robust Regression \\
\hline Constant & $?$ & $0.2714^{* * *}(11.67)$ & $0.2714^{* * *}(9.52)$ \\
\hline RDINT & - & $-0.0017 * * *(-3.54)$ & $-0.0017 * *(-2.20)$ \\
\hline RDINTbio & + & $0.0074 * *(2.27)$ & $0.0074 *(1.84)$ \\
\hline Tangible & + & $0.2553^{* * *}(39.22)$ & $0.2553^{* * *}(34.21)$ \\
\hline Growth & + & $0.0027^{* * *}(6.08)$ & $0.0027^{* * *}(5.86)$ \\
\hline SIZE & $+/-$ & $-0.0483^{* * *}(-27.11)$ & $-0.0483^{* * *}(-15.71)$ \\
\hline$R O A$ & - & $-0.1296^{* * *}(-29.82)$ & $-0.1296 *(-1.89)$ \\
\hline Lnsales & + & $0.0599 * * *(37.64)$ & $0.0599^{* * *}(16.00)$ \\
\hline Liquidity & - & $-0.0011^{* * *}(-15.95)$ & $-0.0011^{* * *}(-2.63)$ \\
\hline Industry dummies & & Included & Included \\
\hline Year dummies & & Included & Included \\
\hline F value & & $206.02^{* * *}$ & $154.90^{* * *}$ \\
\hline Adjusted $R^{2}$ & & 0.2176 & 0.2187 \\
\hline$N$ & & 26,535 & 26,535 \\
\hline
\end{tabular}

Note: See Table 2 for variable definitions. $\mathrm{t}$-values are shown in parentheses. ${ }^{*} p<0.10,{ }^{* *} p<0.05,{ }^{* * *} p<0.01$.

Table 5 represents the regression results for Hypothesis 2, the association between the firm's market value and R\&D intensity. The analysis of that relationship reveals nothing new when compared to existing research results. However, R\&D intensity of firms with above-median leverage shows significant negative association with market value $(p<0.01)$. In the case of biotechnology firms, the results are different. $R \& D$ intensity for biotechnology firms, even if their leverage is above median, has a strong positive association with market value $(p<0.01)$. Thus, the results support Hypothesis 2.

There is a perception that debt is disadvantageous to equity holders. According to both the cost transaction theory and the agency theory, the leverage of R\&D-intensive firms tends to be low, due to concerns about cost of debt. High R\&D intensity in firms with high leverage is thought to hinder their growth opportunities and therefore is not rated positively in the market. However, the analysis of 
biotechnology firms reveals that R\&D investment by biotechnology firms is always positively evaluated in the market, even if done through debt financing. It should not be overlooked, however, that there may be excessive expectations of the market behind this phenomenon.

There are also significant correlations between the market value of a firm and the control variables. SIZE, MTB, GROW, and INV have positive correlations to market value, while HLEV is negatively correlated. Again, robust regression analysis was performed, and the results remained consistent with the OLS results for the explanatory variables.

Table 5. Regression results.

\begin{tabular}{|c|c|c|c|}
\hline \multirow{2}{*}{ Variables } & \multirow{2}{*}{ Expected Sign } & \multicolumn{2}{|c|}{ Dependent Variable: $T Q$} \\
\hline & & OLS Regression & Robust Regression \\
\hline Constant & $?$ & $-1.1842 * * *(-4.68)$ & $-1.1842^{* * *}(-5.13)$ \\
\hline HRDINT & + & $0.1830 * * *(5.46)$ & $0.1830 * * *(5.23)$ \\
\hline HRDINTHLEV & - & $-0.2077^{* * *}(-4.23)$ & $-0.2077^{* * *}(-4.36)$ \\
\hline HRDINTHLEVbio & + & $0.3445 * * *(2.99)$ & $0.3445 * *(2.19)$ \\
\hline SIZE & $+/-$ & $0.0434^{* * *}(4.57)$ & $0.0434^{* * *}(4.58)$ \\
\hline HLEV & - & $-0.7298^{* * *}(-20.97)$ & $-0.7298^{* * *}(-22.69)$ \\
\hline GROW & + & $0.6167^{* * *}(72.65)$ & $0.6168^{* * *}(22.19)$ \\
\hline MTB & + & $0.9645^{* * *}(75.48)$ & $0.9645^{* * *}(45.67)$ \\
\hline$I N V$ & + & $1.2065^{* * *}(31.36)$ & $1.2065^{* * *}(9.96)$ \\
\hline Industry dummies & & Included & Included \\
\hline Year dummies & & Included & Included \\
\hline F value & & $1068.61^{* * *}$ & $171.87^{* * *}$ \\
\hline Adjusted $R^{2}$ & & 0.6394 & 0.6400 \\
\hline$N$ & & 21,673 & 21,673 \\
\hline
\end{tabular}

Note: See Table 2 for variable definitions. t-values are shown in parentheses. ${ }^{*} p<0.10,{ }^{* *} p<0.05,{ }^{* * *} p<0.01$.

Table 6 presents the regression results for Hypothesis 3. The market responds less negatively to firms with higher short-term debt ratios, which occurs when the firm's short-term leverage is greater than long-term leverage, when compared to firms with a high level of leverage overall. The market also responds less negatively to the R\&D intensity of firms with higher short-term debt ratios, but in the case of biotechnology firms, no significant difference was found.

Table 6. Regression results.

\begin{tabular}{|c|c|c|c|}
\hline \multirow{2}{*}{ Variables } & \multirow{2}{*}{ Expected Sign } & \multicolumn{2}{|c|}{ Dependent Variable: $T Q$} \\
\hline & & OLS Regression & Robust Regression \\
\hline Constant & $?$ & $-0.3766(-1.44)$ & $-0.3766(-1.58)$ \\
\hline HRDINT & + & $0.1895 * * *(5.77)$ & $0.1895^{* * *}(5.44)$ \\
\hline HRDINTSTD & - & $-0.1781 * * *(-3.48)$ & $-0.1781^{* * *}(-3.66)$ \\
\hline HRDINTSTDbio & + & $0.2745 * *(2.40)$ & $0.2745 * *(2.11)$ \\
\hline$S I Z E$ & $+/-$ & $-0.0220^{* *}(-2.28)$ & $-0.0220^{* *}(2.29)$ \\
\hline STD & - & $-0.1838^{* * *}(-5.13)$ & $-0.1838^{* * *}(-5.62)$ \\
\hline GROW & + & $0.6305^{* * *}(72.70)$ & $0.6305^{* * *}(22.27)$ \\
\hline MTB & + & $0.9130^{* * *}(70.06)$ & $0.9130^{* * *}(43.05)$ \\
\hline$I N V$ & + & $1.0978^{* * *}(28.00)$ & $1.0978^{* * *}(8.94)$ \\
\hline Industry dummies & & Included & Included \\
\hline Year dummies & & Included & Included \\
\hline F value & & $997.98^{* * *}$ & $157.78^{* * *}$ \\
\hline Adjusted $R^{2}$ & & 0.6235 & 0.6241 \\
\hline$N$ & & 21,673 & 21,673 \\
\hline
\end{tabular}

Note: See Table 2 for variable definitions. t-values are shown in parentheses. ${ }^{*} p<0.10,{ }^{* *} p<0.05,{ }^{* * *} p<0.01$.

One potential solution to the underinvestment problem is to use short-term debts [10]. If a firm desperately needs to rely on debt financing, it tends to prefer less-risky short-term debts. According to 
existing evidence, short-term debts to total debts ratio is positively correlated with R\&D intensity. The results of this study confirm that the use of short-term debts mitigate the negative impact of debt financing, though this does not seem to apply to biotechnology firms. In conclusion, the market appears to put great emphasis on how aggressively the firm is investing in $R \& D$, as well as the success of the investment. The capital structure per se does not seem to matter, particularly for biotechnology firms.

There are again significant correlations between the market value of a firm and the control variables. MTB, GROW, and INV have positive correlations to market value, while STD is negatively correlated. A fixed-effect regression analysis was also conducted. As with the previous datasets, robust regression analysis was performed, and the results remained consistent with the OLS results for the explanatory variables.

\subsection{Additional Analyses}

Additional analyses have been conducted using dummy variables for short-term \& long-term debt. As can be seen in Table 7, the results were robust when run through additional analyses.

Table 7. Regression results.

\begin{tabular}{cccc}
\hline \multirow{2}{*}{ Variables } & \multirow{2}{*}{ Expected Sign } & \multicolumn{2}{c}{ Dependent Variable: TQ } \\
\cline { 3 - 4 } & & Short-Term Debt & Long-Term Debt \\
\hline Constant & $?$ & $-0.2398(-0.95)$ & $-1.1830^{* * *}(-4.58)$ \\
HRDINT & + & $0.2120^{* * *}(6.00)$ & $0.1914^{* * *}(5.56)$ \\
HRDINTHHSTLEV & - & $-0.1998^{* * *}(-4.02)$ & \\
HRDINTHHSTLEVbio & + & $0.2291^{* * *}(2.31)$ & \\
HRDINTHHLTLEV & - & & $-0.1556^{* * *}(-3.11)$ \\
HRDINTHHLTLEVbio & + & & $0.6661^{* * *}(7.23)$ \\
SIZE & +- & $-0.0161^{* *}(-1.69)$ & $0.0295^{* * *}(3.02)$ \\
HSTLEV & - & $-0.4022^{* * *}(-11.45)$ & \\
HLTLEV & - & & $-0.3815^{* * *}(-10.66)$ \\
GROW & + & $0.6234^{* * *}(72.37)$ & $0.6118^{* * *}(70.47)$ \\
MTB & + & $0.9066^{* * *}(70.07)$ & $0.9257^{* * *}(71.54)$ \\
INV & + & $1.1474^{* * *}(29.43)$ & $1.1957^{* * *}(30.38)$ \\
Industry dummies & & Included & Included \\
Year dummies & & Included & Included \\
\hline F value & & $1018.88^{* * *}$ & $1013.39^{* * *}$ \\
Adjusted $R^{2}$ & & 0.6284 & 0.6271 \\
$N$ & & $21,673^{*}$ & 21,673
\end{tabular}

Note: HRDINTHHSTLEV: The interaction between HRDINT and HSTLEV. HSTLEV is coded as 1 if the short-term debts divided by total assets is above the median, and as 0 otherwise. HRDINTHSTLEVbio: The interaction between HRDINTSTLEV and BIO, the biotech dummy variable. HRDINTHHLTLEV: The interaction between HRDINT and HLTLEV. HLTLEV is coded as 1 if the long-term debts divided by total assets is above the median, and as 0 otherwise. HRDINTHLTLEVbio: The interaction between HRDINTLTLEV and BIO, the biotech dummy variable. See Table 2 for variable definitions. t-values are shown in parentheses. ${ }^{*} p<0.10,{ }^{* *} p<0.05,{ }^{* * *} p<0.01$.

\section{Conclusions}

This issue was brought to light when, in 2018, the prices of biotechnology stocks soared in the Korean stock market. As information asymmetry within firms grows and competition between firms intensifies, the importance of R\&D in the sustainable success of a firm becomes more apparent. In a global marketplace with ever-evolving consumer needs, innovation has become vital. In order to sustain growth in this competitive environment, firms must not only develop successful products, but also continually innovate and create demand. In response, firms have begun to focus on investment in $R \& D$ in order to stay competitive.

This study documents that firms with high R\&D intensity are less likely to finance from the debt market; however, such a tendency is not found in biotechnology firms. The results imply that the biotechnology industry, unlike other industries, tend to maintain a relatively constant degree of R\&D 
investment through debt financing, even with a high rate of uncertainty. This tendency may be driven by the distinct strategy of biotechnology firms to conduct R\&D activity in order to pursue long-term sustainability regardless of its effect on short-term profitability. Moreover, the uncertainty and information asymmetry derived from R\&D activities increase additional firm-specific risks on debtholders; investment in R\&D with leverage therefore decreases firm value [18]. However, biotechnology firms did not show any decline in firm value even with debt financing. A lack of financing can be disastrous to biotechnology firms, which must somehow fund their intense R\&D. In order to maintain investment, these firms must often find external sources of capital, and compared to equity financing, debt financing is superior for managing proprietary corporate information, which results in a high firm value despite high leverage. In spite of numerous concerns and controversies, recently, South Korea's financial authorities have decided to ease listing conditions for biotechnology firms by supporting external financing for R\&D activities, with some expectation that the guidelines would be strengthened following a number of supervision cases of biotechnology firms' R\&D accounting treatment. In this case, the financial authorities appear to have chosen to consider the reality of the domestic biotechnology industry, potentially resulting in a growth comparable to global standards.

Meanwhile, with the advent of the fourth industrial revolution, open innovation has become the corporate core strategy for sustainable growth and possible survival. Small changes in individual adaptation strategies can lead to substantial changes throughout the system [61]. Depending on the business life cycle or market conditions, open innovation strategies can be taken or discarded $[62,63]$. The biotechnology industry is no exception. According to 'Deloitte's 2017 Global Health Sciences Outlook Report', the probability of success in developing new drugs through the open innovation model is three times higher than that of conventional closed models. Furthermore, the environment for the biotech industry has been changing in favor of businesses. For example, global biopharmaceutical companies have been supporting open innovation together with Korean start-ups. The Korean government has been providing comprehensive benefits for companies that are pursuing open innovation strategies. In this regard, it could be advantageous for biotechnology companies to adopt open innovation strategies taking into account both the internal circumstances-for example what stage a firm is in, and the external environment.

This paper provides important contributions to the literature. First, the study offers a profound understanding on the effect of intraindustry variations on corporate capital structure and firm value. According to KoreaBIO, 281 of the 926 (30.3\%) biotechnology companies have reported either no or almost no sales, and $343(37.0 \%)$ of those firms are yet to achieve the breakeven point (Korea Biotechnology Industry Organization). Though the growth of biotechnology firms can be incredible, many consider their stock prices to be inflated, despite their low fundamentals. In order to identify this discrepancy, policy makers and investors must understand the behaviors of biotechnology firms, as empirically shown in this study, and consider ways to support their future sustainability and growth. Second, the evidence in this study can be of interest to investors of biotechnology firms. Investors who are likely to invest in the Korean biotechnology firms could benefit from the adverse empirical results of this study as it reports that biotechnology firms that steadily invest in R\&D are able to create value for debtholders by sustaining profits thereby increasing leverage, whereas the literature showed that corporate originality and profitability had a negative relationship to its debt ratios [7]. Finally, even though prior studies investigate the association between R\&D intensity, capital structure, and corporate firm value mostly by focusing on the developed countries such as European Union and US, there is rare evidence from emerging market due to the differences in development speed of biotechnology industry. This paper may fill this gap by documenting the different pattern of external financing for R\&D activities in biotechnology firms.

This paper is subject to several limitations. For instance, despite the fact that focus on the biotechnology industry offers a powerful setting to investigate the research questions, it can also restrain the generalizability of the empirical findings to other industries. Furthermore, although this study incorporates robust regression, there can exist the possibility of omitted variable problems. This is 
because we are not able to precisely measure the corporate $R \& D$ intensity due to the difficulty that $R \& D$ intensity is affected by the managerial discretionary judgement on that activity. However, this paper still contributes to the literature through its research on the relationship between R\&D and leverage, debt types, and firm value of both biotechnology and nonbiotechnology firms. It is also important to consider the unique conditions of South Korea, where financial authorities have recently implemented new guidelines to support the R\&D of biotechnology firms. Supervisory authorities are now focused on error correction rather than punishment, which promotes the potential growth of that industry.

Author Contributions: Conceptualization, J.L.; methodology, N.L.; software, N.L.; validation, J.L. and N.L.; formal analysis, N.L.; investigation, N.L.; resources, N.L.; data curation, N.L.; writing-original draft preparation, J.L.; writing一review and editing, J.L.; supervision, J.L. and N.L.

Funding: This research received no external funding.

Conflicts of Interest: The authors declare no conflict of interest.

\section{References}

1. Chandler, A.D. Scale and Scope: The Dynamics of Industrial Capitalism; Harvard University Press: Boston, MA, USA, 1994.

2. Kaplan, R.S.; Norton, D.P. The Strategy-Focused Organization: How Balanced Scorecard Companies Thrive in the New Business Environment; Harvard Business School Press: Boston, MA, USA, 2001.

3. Ittner, C.D.; Larcker, D.F.; Randall, T. Performance Implications of Strategic Performance Measures in Financial Services Firms. Account. Organ. Soc. 2003, 28, 715-741. [CrossRef]

4. Tufts, C.S. Post-approval R D raises total drug development costs to $\$ 897$ million. Impact Rep. $2013,5,3$.

5. Nelson, R.R.; Winter, S.G. An Evolutionary Theory of Economic Change; Belknap Press of Harvard University Press: Cambridge, MA, USA, 1982.

6. Brown, J.R.; Petersen, B.C. Why has the investment-cash flow sensitivity declined so sharply? Rising R\&D and equity market developments. J. Bank. Financ. 2009, 33, 971-984.

7. Titman, S.; Wessels, R. The determinants of capital structure. J. Financ. 1988, 43, 1-19. [CrossRef]

8. Gaver, J.J.; Gaver, K.M. Additional evidence on the association between the investment opportunity set and corporate financing, dividend and compensation policies. J. Account. Econ. 1993, 16, 125-160. [CrossRef]

9. Brown, J.R.; Fazzari, S.M.; Petersen, B.C. Financing innovation and growth: Cash flow, external equity, and the 1990s R\&D boom. J. Financ. 2009, 64, 151-185.

10. Myers, S.C. Determinants of corporate borrowing. J. Financ. Econ. 1977, 5, 147-175. [CrossRef]

11. Jensen, M.C.; Meckling, W.H. Theory of the firm: Managerial behavior, agency costs and ownership structure. J. Financ. Econ. 1976, 3, 305-360. [CrossRef]

12. Jensen, M. Agency cost of free cash flow, corporate finance and takeovers. Am. Econ. Rev. 1986, 76, 323-329.

13. Amore, M.D.; Schneider, C.; Žaldokas, A. Credit supply and corporate innovation. J. Financ. Econ. 2013, 109, 835-855. [CrossRef]

14. Chava, S.; Oettl, A.; Subramanian, A.; Subramanian, K.V. Banking deregulation and innovation. J. Financ. Econ. 2013, 109, 759-774. [CrossRef]

15. Aboody, D.; Lev, B. Information asymmetry, R\&D, and insider gains. J. Financ. 2000, 55, 2747-2766.

16. Shleifer, A.; Vishny, R.W. Equilibrium short horizons of investors and firms. Am. Econ. Rev. 1990, 80, $148-153$.

17. Vincente-Lorente, J.D. Specificity and opacity as resource-based determinants of capital structure: Evidence for Spanish manufacturing firms. Strateg. Manag. J. 2001, 22, 157-177. [CrossRef]

18. Shi, C. On the trade-off between the future benefits and riskiness of R\&D: A bondholders' perspective. J. Account. Econ. 2003, 35, 227-254.

19. Roberts, P.W. Product innovation, product-market competition and persistent profitability in the US pharmaceutical industry. Strateg. Manag. J. 1999, 20, 655-670. [CrossRef]

20. Modigliani, F.; Miller, M. Taxes and the cost of capital: A correction. Am. Econ. Rev. 1963, 53, $433-443$.

21. Miller, M.H. Debt and Taxes. J. Financ. 1977, 32, 261-275.

22. Baxter, N. Leverage, risk of ruin and the cost of capital. J. Financ. 1967, 21, 395-403.

23. Scott, J., Jr. Bankruptcy, Secured Debt, and Optimal Capital Structure. J. Financ. 1977, 32, 1-19. [CrossRef]

24. Harris, M.; Raviv, A. The theory of capital structure. J. Financ. 1991, 46, 297-355. [CrossRef] 
25. Berle, A.; Means, G. The Modern Corporation and Private Property; Harcourt, Brace, and World: New York, NY, USA, 1932.

26. Ross, S. The determination of financial Structure: The incentive-signaling approach. Bell J. Econ. 1977, 8, 23-40. [CrossRef]

27. Myers, S.; Majluf, N. Corporate financing and investment decisions when firms have information that investors do not have. J. Financ. Econ. 1984, 13, 187-221. [CrossRef]

28. Rajan, R.; Zingales, L. What do we know about capital structure? Some evidence from international data. J. Financ. 1995, 50, 1421-1460. [CrossRef]

29. Fama, E; French, K.P. Testing Tradeoff and Pecking Order Predictions about Dividends and Debt. Rev. Financ. Stud. 2002, 15, 1-33. [CrossRef]

30. Jin, Z.; Shang, Y.; Xu, J. The impact of government subsidies on private R\&D and firm performance: Does ownership matter in China's manufacturing industry? Sustainability 2018, 10, 2205.

31. Xu, J.; Sim, J. Characteristics of Corporate R\&D Investment in Emerging Markets: Evidence from Manufacturing Industry in China and South Korea. Sustainability 2018, 10, 3002.

32. Girotra, K.; Terwiesch, C.; Ulrich, K.T. Valuing R\&D projects in a portfolio: Evidence from the pharmaceutical industry. Manag. Sci. 2007, 53, 1452-1466.

33. Bhattacharya, S.; Ritter, J.R. Innovation and communication: Signaling with partial disclosure. Rev. Econ. Stud. 1983, 50, 331-346. [CrossRef]

34. Lu, C.W.; Chen, T.K.; Liao, H.H. Information uncertainty, information asymmetry and corporate bond yield spreads. J. Bank. Financ. 2010, 34, 2265-2279. [CrossRef]

35. Cyert, R.M.; March, J.G. A Behavioral Theory of the Firm, 2nd ed.; Prentice-Hall: Upper Saddle River, NJ, USA, 1963.

36. Nelson, R.R. Why do firms differ, and how does it matter? Strateg. Manag. 1991, 12, 61-74. [CrossRef]

37. Schumpeter, J. Capitalism, Socialism, and Democracy; Harper and Brothers: New York, NY, USA, 1942.

38. Cohen, W.; Levinthal, D. Absorptive capacity: A new perspective on learning and innovation. Adm. Sci. Q. 1990, 35, 128-152. [CrossRef]

39. Chan, S.H.; Martin, J.D.; Kensinger, J.W. Corporate research and development expenditure and share value. J. Financ. Econ. 1990, 26, 255-276. [CrossRef]

40. Bae, S.C.; Noh, S. Multinational corporations versus domestic corporations: A comparative study of R\&D investment activities. J. Multinatl. Financ. Manag. 2001, 11, 89-104.

41. Ho, Y.K.; Keh, H.T.; Ong, J.M. The effect of R\&D and advertising on firm value: An examination of manufacturing and nonmanufacturing firms. IEEE Trans. Eng. Manag. 2005, 52, 3-14.

42. Bae, S.C.; Park, B.J.; Wang, X. Multinationality, R\&D intensity, and firm performance: Evidence from U.S. manufacturing firms. Multinatl. Bus. Rev. 2008, 16, 53-77.

43. Walwyn, D. Finland and the mobile phone industry: A case study of the return on investment from government-funded research and development. Technovation 2007, 27, 335-341. [CrossRef]

44. Karlsson, M.; Trygg, L.; Elfsstrom, B. Measuring R\&D productivity: Complementing the picture by focusing on research activities. Technovation 2004, 24, 176-186.

45. Hall, B.H. The stock market's valuation of R\&D investment during the 1980s. Am. Econ. Rev. 1993, 83, $259-264$.

46. Erickson, G.; Jacobson, R. Gaining Comparative Advantage through Discretionary Expenditures: The Returns to R\&D and Advertising. Manag. Sci. 1992, 38, 1264-1279.

47. Honore, F.; Munari, F.; de La Potterie, B. Corporate Governance Practices and Companies R\&D Intensity: Evidence from European Countries. Res. Policy 2015, 44, 533-543.

48. McConnell, J.J.; Servaes, H. Additional Evidence on Equity Ownership and Corporate Value. J. Financ. Econ. 1990, 27, 595-612. [CrossRef]

49. Cai, J.; Zhang, Z. Leverage change, debt overhang, and stock prices. J. Corp. Financ. 2011, 17, $391-402$. [CrossRef]

50. Fama, E.F.; French, K.R. Common risk factors in the returns on stocks and bonds. J. Financ. Econ. 1993, 33, 3-56. [CrossRef]

51. Osawa, Y.; Yamasaki, Y. Proposal of industrial research and development performance indices. RD Manag. 2005, 35, 455-461. [CrossRef]

52. Damodaran, A. Applies Corporate Finance, 3rd ed.; John Wiley Sons: Hoboken, NJ, USA, 2010.

53. Bah, R.; Dumontier, P. R\&D intensity and corporate financial policy: Some international evidence. J. Bus. Financ. Account. 2001, 28, 671-692. 
54. Aghion, P.; Klemm, A.; Bond, S.I.; Marinescu, I. Technology and financial structure: Are innovative firms different? J. Eur. Econ. Assoc. 2004, 2, 277-288. [CrossRef]

55. Williamson, O. Corporate Finance and Corporate Governance. J. Financ. 1988, 43, 567-591. [CrossRef]

56. McConnell, J.J.; Servaes, H. Equity ownership and the two faces of debt. J. Financ. Econ. 1995, 39, $131-157$. [CrossRef]

57. Simon, C.J.; Sullivan, M.W. The Measurement and Determinants of Brand Equity: A Financial Approach. Mark. Sci. 1993, 12, 28-52. [CrossRef]

58. Rao, A.R.; Ruekert, R.W. Brand Alliances as Signals of Product Quality. Sloan Manag. Rev. 1994, 36, 87-97.

59. Dahya, J.; McConnell, J. Board Composition, Corporate Performance and the Cadbury Committee Recommendation. J. Financ. Quant. Anal. 2007, 42, 535-564. [CrossRef]

60. Freel, M.S. The financing of small firm product innovation within the UK. Technovation 1999, 19, 707-719. [CrossRef]

61. Witt, U. Capitalism as a complex adaptive system and its growth. J. Open Innov. Technol. Mark. Complex. 2017, 3, 1-15. [CrossRef]

62. Battistella, C.; de Toni, A.; Pessot, E. Framing Open Innovation in Start-Ups' Incubators: A Complexity Theory Perspective. J. Open Innov. Technol. Mark. Complex. 2018, 4, 33. [CrossRef]

63. Yun, J.J.; Won, D.; Park, K. Dynamics from open innovation to evolutionary change. J. Open Innov. Technol. Mark. Complex. 2016, 2, 1-22. [CrossRef]

(C) 2019 by the authors. Licensee MDPI, Basel, Switzerland. This article is an open access article distributed under the terms and conditions of the Creative Commons Attribution (CC BY) license (http://creativecommons.org/licenses/by/4.0/). 